\title{
Framework Development Methodology for Sustainable Procurement of Construction Works in Indonesia
}

\author{
Muhamad Abduh ${ }^{1, *}$, Reini D. Wirahadikusumah ${ }^{1}$, and Yunita Messah ${ }^{1}$ \\ ${ }^{1}$ Institut Teknologi Bandung, Ganesha 10 Bandung, Indonesia
}

\begin{abstract}
To implement sustainable development in construction sector, or called as sustainable construction, Indonesian still face challenges that requires massive research and developments related to that issue. One of the most important practices in sustainable construction is adoption of sustainable principle in procurement processes or called sustainable procurement. This paper will discuss a methodology formulation that is designed to develop a framework for implementing sustainable procurement in construction projects. The framework will consist of important factors driving the sustainable procurement system and their relationships to effectively produce the outputs of procurement processes that meets sustainable principles.
\end{abstract}

\section{Introduction}

Indonesia as a developing country must put more pace into the infrastructure development to support its ever-growing population, not only for today's needs, but also for the future. However, the development activities have been conducted with unintegrated approach and merely based on sectors; forgetting systemic and ecological approach, prioritizing most on short-term outcomes, ignoring the holistic and comprehensive prospects of sustainability. Such practices of development could lead to cause environmental damages due to uncontrolled production and consumption; construction activities that are supporting the development require large amounts of natural resources. The Indonesian construction industry is aware of the threats as results of its current practices and would like to adopt sustainable development principles into construction activities; this is known as sustainable construction [1]. Sustainable construction concept provides a set of processes for generating built assets (infrastructure, buildings) sustainable and on the other hand would improve quality of life and customer satisfaction, offer flexibility for future changes, provide and support the desired natural and social environments, and used resource efficiently [2].

In 2015 , the Indonesian government issued a ministry level regulation as a guidance to implement sustainable construction principles, but only limited to build government funded infrastructure. The principles were adopted from the seven CIB (Conseil International du

*Corresponding author; abduh@si.itb.ac.id 
Bâtiment or International Council for Building) sustainable construction principles [3] and then customized to fit with the Indonesian construction industry practices. Those principles include: setting-up common goals, understanding and action plans; reducing the use of resources, whether in the form of land, materials, water, natural resources and human resources; reduction of waste generation, both physical and non-physical wastes; reuse of previously used resources; use of recycled resources; protection and management of the environment through conservation efforts; mitigation of safety, health, climate and disaster risks; orientation to the life cycle; orientation to the desired quality achievement; technological innovation for continuous improvement; and institutional support, leadership and management in implementation. Those sustainable principles are covering economic, social and environmental aspects already and are to be implemented in using any resources that would be considered and consumed in all stages of the infrastructure life cycle: programming, designing, construction, operation and maintenance, and de-construction [4].

\section{Sustainable Procurement in Construction}

In construction sector, an owner plays very important role throughout the stages of the infrastructure life cycle. The need to comply with sustainable construction principles, therefore should origin from the owner from the first place; it is commonly known as value that is defined by the owner. In this case, the owner would bring along this targeted value throughout the life cycle of the infrastructure. Since the owner's capacity is limited to do all necessary activities by itself, the owner need procurement system that would bring other parties to help the owner achieving the targeted value. In this context, the procurement system is then very important to achieve the sustainable construction principles due to segmented industry that the construction sector has. It can be said firmly that sustainable principles in construction can be met through special procurement system that is further called as sustainable procurement [5].

In general, procurement can be viewed as an integral process of any construction project that includes all activities related to the provision of goods, services and consultations necessary to achieve the project objectives [6,7]. However, it is also found that there is a chance that the procurement could affect the sustainability performance of construction projects $[8,9,10]$. With those findings, procurement of construction can also be stimulated to promote national sustainability agenda even though current procurement practices in construction have been heavily criticized for neglecting sustainability in the project life cycle. This is merely due to procurement practice in selecting third parties to do the services still used the lowest bid system. On the other hand, current practices in green building projects, which can be considered to have implement sustainable construction principles, the contractors only concentrated more on economic and environmental aspects, such as green practices and behaviour, but excluded the social aspects $[2,11,12]$. There is a need to develop specialist sub-contractors and suppliers, that are aware of and practicing sustainability principles in their businesses to provide a competitive sustainable construction market in Indonesia [13].

Practices of sustainable construction procurement in developed countries has been a while performed by private sector as well as the public sector. It was reported that the public procurement is very potential for pushing sustainability agenda of a country widely due to large its volume of procurements [14]; realizing this potential, the Indonesian government procurement policy agency, or in Indonesian abbreviated as LKPP, has developed a roadmap of its sustainable public procurement development.

The implementation of sustainable procurement by the private construction sector is on voluntary mode based on sustainability awareness and more flexible private sector's practices. Some Indonesian private developers already recognized the need of sustainable 
procurement in realizing sustainable development. However, during the implementation, there are still reluctances and difficulties to put in action some principles of sustainability into technical specifications and evaluation processes. Some obstacles were identified including: persistence to remain unchanged; behaviour that is influenced by local culture; priority conflict; lack of education and trainings; lack of research and development; limited resources and sustainable products; bad quality; lack of funding; lack of awareness, understanding, information, commitment, demand, and guidance; lack of definition and varied interpretations; lack of perspective and long-term observation and integration and linkage in industry; and perception of applying sustainability always leads to an increase in capital costs [15]. However, the obstacles were also found practice of sustainable procurement of construction in England, Canada, Ghana and Malaysia [16].

\section{The Need of Framework for Sustainable Procurement}

Even though Indonesian construction industry has been aware of the important of sustainability and has put some efforts to build commitment towards sustainable construction and especially sustainable procurement, various obstacles that existed have been the challenges to overcome and have pointed out that a strategy related to implementation of sustainable procurement is urgently needed. Yet, before going further to develop the strategy, clear understanding of all conditions and aspects of construction procurement system, in the context of Indonesian construction industry, should be identified and then projected to accommodate the implementation of sustainable construction principles. More challenges emerging from every aspect of sustainable procurement then could be mapped with their relationships towards successful strategy of the implementation. For this purpose, a framework of sustainable procurement for construction works is needed.

A framework itself, based on many dictionaries, could be related to a structure that could build something upon $[17,18,19]$. The structure could be simple or complex; in the case of complex one, the structure should have components that are related to each other or support one and another. At the end, the structure itself should have purpose of existence; all the component should contribute to effectively to this purpose. In the context of sustainable procurement, a framework is defined as a structure, consisting significant components of procurement system that support each other effectively, that would make the procurement processes conducted effectively in achieving sustainable principles. This framework would be designed to assist both public owners and private sectors in dealing with developing sustainable procurement policies, strategies and processes. Moreover, this framework may also be used by all parties involved in procurement as a guide to implement sustainable procurement practices, performance assessment, and continuous improvement $[20,21,22]$.

Since sustainable procurement for Indonesian construction industry is a relatively new topic, the development of sustainable procurement framework for construction works is challenging. Facts related to construction procurement in Indonesia may be available to be studied, but the sustainable procurement practices are still in introduction phase and not much successful as well as failed cases could be used as basis for the development of the framework. In the meantime, the developed framework should always be flexible for future development and valid to cover the Indonesian construction industry contexts and needs. Therefore, an appropriate methodology to develop the intended framework should be determined first. 


\section{Methodology Development}

In developing the methodology, several steps in creating the framework should be considered and analysed. Firstly, it begins with basing the framework on well-established ones, and then selecting a founding framework that would become a reference, and lastly formulating the framework itself [23].

\subsection{Well-established Frameworks for Sustainable Procurement}

Since sustainable procurement is relatively new to Indonesian construction industry, there is no need to make a brand-new framework specifically for this purpose. Instead, it wise to seek well-established sustainable procurement frameworks in other countries or in other industries, even though the context may be different from Indonesia. Finding the different contextual system, application and environment are the main issues after deleting the invalid frameworks as basis of the framework development in the first place. The following Table 1 contains the results of literature studies to find relevant frameworks available related to sustainable procurement.

\subsection{Reference Frameworks Selection}

As suggested, the selection process to find the founding frameworks could be done based on its establishment and popularity among researchers and practitioners. This will be enough to provide evidence of conceptual acceptance and applicability of the selected frameworks [23]. Based on Table 1, as listed before, and further literature review, there are four frameworks related to sustainable procurement, that could meet criteria of establishment and popularity. They are frameworks according to the Department of Food Rural and Affairs (DEFRA) [24], British Standard (BS) 8903 [25], Wahid [26], and Sourani [27].

Even though there are four frameworks available in sustainable procurement, it is obvious that all has common basis framework, i.e., the DEFRA's framework. All three other frameworks are confidently developed based on this DEFRA's framework with additional features or customization to meet contextual needs. The DEFRA's framework itself is a voluntary standard for measuring the US Government's progress in meeting its objectives for sustainable procurement. This DEFRA's sustainable procurement framework was popular as a reference in formulation of sustainable procurement framework including in construction sector $[28,29]$. The sustainable procurement framework under BS 8903 is adopted from DEFRA's framework and has links to five elements in DEFRA's framework: Human Resources; Policy; Strategy and Communication; Procurement Process; Involving Suppliers; and Measurement and Results [30]. The framework according to Wahid's model was a framework for sustainable procurement based on the constraints and critical factors in sustainable procurement that took place in the UK and European countries. Whilst, the framework according to Sourani's model was a theoretical framework related to sustainability integrity in British construction procurement strategy.

Based on four founding frameworks, Table 2 depicts the elements considered in each framework. Further question would be how those four frameworks be utilized to find the framework that meet the Indonesian construction industry practices and conditions. The attachment of this paper elaborates the elements that will be explored further their aptness to Indonesian context based on the four frameworks. 
Table 1. Sustainable Procurement Framework

\begin{tabular}{|c|c|c|c|c|c|}
\hline No & Literature & Location & $\begin{array}{l}\text { Public/ } \\
\text { Private }\end{array}$ & $\begin{array}{c}\text { General/ } \\
\text { Construction }\end{array}$ & Remark \\
\hline 1 & $\begin{array}{l}\text { DEFRA } \\
(2006)\end{array}$ & $\begin{array}{c}\text { United } \\
\text { Kingdom }\end{array}$ & Public & General & $\begin{array}{l}\text { This framework has been } \\
\text { tested by various public- } \\
\text { sector stakeholders and } \\
\text { supported by the Office of } \\
\text { Government Commerce } \\
\text { (OGC). The focus of the } \\
\text { framework is on } \\
\text { identification of good } \\
\text { sustainable procurement } \\
\text { basics. The framework } \\
\text { ensures a consistent } \\
\text { approach to risk } \\
\text { management } \\
\text { encourages the organization } \\
\text { to seize the opportunity to } \\
\text { stimulate innovation in its } \\
\text { supply chain. }\end{array}$ \\
\hline 2 & $\begin{array}{l}\text { APCC } \\
(2007)\end{array}$ & $\begin{array}{c}\text { Australia } \\
\& \text { New } \\
\text { Zealand }\end{array}$ & Public & Construction & $\begin{array}{l}\text { It is built on the premise } \\
\text { that sustainable } \\
\text { procurement balances } \\
\text { economic, environmental } \\
\text { and social considerations in } \\
\text { procurement process. It } \\
\text { supports and encourages } \\
\text { collaboration between } \\
\text { governmental jurisdictions } \\
\text { to develop national } \\
\text { programs and devices. The } \\
\text { goal is to promote } \\
\text { sustainable procurement } \\
\text { principles and share } \\
\text { experiences, given that } \\
\text { sustainability issues is not } \\
\text { limited by jurisdictional } \\
\text { boundaries. However, this } \\
\text { framework is lacking in a } \\
\text { holistic approach and its } \\
\text { indicators. }\end{array}$ \\
\hline 3 & $\begin{array}{l}\text { BS 8903 } \\
(2010)\end{array}$ & $\begin{array}{c}\text { United } \\
\text { Kingdom }\end{array}$ & Public & Construction & $\begin{array}{l}\text { This framework is adopted } \\
\text { from the DEFRA } \\
\text { framework. Elements in the } \\
\text { DEFRA framework are } \\
\text { described in BS } 8903 \text {. }\end{array}$ \\
\hline 4 & $\begin{array}{l}\text { Wahid } \\
(2014)\end{array}$ & Malaysia & Public & Construction & $\begin{array}{l}\text { Formulation of this } \\
\text { framework begins with a } \\
\text { critical review of the public } \\
\text { procurement policies of } \\
\text { countries and/or regions, } \\
\text { namely England and } \\
\text { Europe. Elements of } \\
\text { sustainable procurement } \\
\text { developed from several } \\
\text { literatures. }\end{array}$ \\
\hline
\end{tabular}




\begin{tabular}{|c|l|l|l|l|l|}
\hline No & Literature & Location & $\begin{array}{l}\text { Public/ } \\
\text { Private }\end{array}$ & $\begin{array}{c}\text { General/ } \\
\text { Construction }\end{array}$ & \multicolumn{1}{c|}{ Remark } \\
\hline 5 & $\begin{array}{l}\text { Sourani } \\
(2008)\end{array}$ & $\begin{array}{c}\text { United } \\
\text { Kingdom }\end{array}$ & Public & Construction & $\begin{array}{l}\text { The framework is } \\
\text { evidence-based and } \\
\text { comprehensive, providing a } \\
\text { clear vision of what needs } \\
\text { to be addressed and what } \\
\text { enables the achievement of } \\
\text { sustainable construction } \\
\text { procurement by UK public } \\
\text { clients. It also anticipates } \\
\text { what obstacles and who is } \\
\text { best placed to overcome } \\
\text { them. Framework begins by } \\
\text { identifying criteria related } \\
\text { to social, economic and } \\
\text { environmental aspects, } \\
\text { important factors, obstacles } \\
\text { and who is responsible. } \\
\text { Objective is to formulate a } \\
\text { sustainable construction } \\
\text { procurement strategy. }\end{array}$ \\
\hline
\end{tabular}

Table 2. Elements of Sustainable Procurement based on Four Frameworks

\begin{tabular}{|l|c|c|c|c|}
\hline \multicolumn{1}{|c|}{ Elements } & DEFRA & BS 8903 & Wahid & Sourani \\
\hline Human Resources (People) & $\sqrt{ }$ & $\sqrt{ }$ & & $\sqrt{ }$ \\
\hline Policy and Strategy & $\sqrt{ }$ & $\sqrt{ }$ & & $\sqrt{ }$ \\
\hline Communication & $\sqrt{ }$ & $\sqrt{ }$ & $\sqrt{ }$ & \\
\hline Process & $\sqrt{ }$ & $\sqrt{ }$ & $\sqrt{ }$ & \\
\hline Engaging Supplier & $\sqrt{ }$ & $\sqrt{ }$ & & \\
\hline Monitoring and Reporting & $\sqrt{ }$ & $\sqrt{ }$ & & \\
\hline Leadership & & & $\sqrt{ }$ & \\
\hline Priority & & & $\sqrt{ }$ & $\sqrt{ }$ \\
\hline Target & & & $\sqrt{ }$ & \\
\hline Standards & & & $\sqrt{ }$ & \\
\hline Participation & & & $\sqrt{ }$ & \\
\hline Support Mechanism & & & $\sqrt{ }$ & \\
\hline Action Plan & & & & $\sqrt{ }$ \\
\hline Knowledge and Perception & & & & $\sqrt{ }$ \\
\hline Regulation & & & & $\sqrt{ }$ \\
\hline Contract & & & & $\sqrt{ }$ \\
\hline Instrument & & & & $\sqrt{ }$ \\
\hline Finance & & & & \\
\hline
\end{tabular}

\subsection{Methodology Formulation}

Before formulating the methodology, there are several literatures mentioning different approaches in formulation the methodology for developing a sustainable procurement framework that should be considered and criticized. They are:

1. In developing a theoretical framework to measure business performance in construction, the process of formulation includes four basic steps: identification of important factors in sustainable procurement; identification of underlying relationship between factors; adaptation of construction; and comprehensive evaluation. The first step integrates 
essential reference frameworks' factors into a set of factors. The second step identifies fundamental relationships between these factors. The importance of this second step is to show how these factors interact and produce procurement results, thus assisting management in isolating procurement issues, understanding its impact and consequently taking appropriate action [23].

2. According to green procurement framework for construction projects in Malaysia, the process of formulating this framework consists of: identifying complications in green procurement practices; important practices for green building procurement; combining practices with factors identified through review literature; analysing comprehensively for framing. The framework is designed to guide stakeholders in planning the implementation of green procurement for construction projects in Malaysia. This framework is built on development of green practices in procurement to develop survey instruments that will be used in the future [31].

3. For developing the framework of sustainable procurement for public construction in Malaysia, the conceptual framework is developed by identifying key elements of sustainable procurement in the UK and European countries. The formulation process of framework then defined each element or factor, identified key factors in sustainable procurement, ranked the factors, and then validated the framework. This framework is developed from a sustainable procurement framework that has been formulated and implemented by various countries [26].

4. Formulation of a framework according to [32] in developing a framework for Supply Chain Planning in Construction is based on existing planning framework: sales planning framework and operational framework. This framework is designed to solve logistics problems, and to develop process planning (procedures) and performance measurement. The process of formulating framework includes: mapping current logistic state in construction to identify problems and performance of logistics (assessing the performance of the supply chain); adjusting shipping/source process; designing the planning process; identifying problems; developing models for interrelationships; developing processes and structures framework.

5. A review on the principle of sustainability of buildings in Malaysia proposed an approach to use a theoretical framework. This framework is developed in accordance to environmental, social, economic aspects of design and innovations that must be measured throughout the development of project, product lifecycle and processes. The theoretical framework is particularly useful for providing crucial guidance for stakeholders and project researchers primarily in formulating clear sustainability principles guidelines for integration into future sustainable building project development in Malaysia. The framework development process begins with preliminary research on the integrated aspects of sustainable buildings, identification of principles for sustainable buildings, identification of independent variables in the application of sustainable building principles, modifying of variables and formulating the framework [33].

6. The Practical Framework for Measuring International Construction Company Performance was developed from implementation of an international contractor performance evaluation conducted in 1992. The formulation of framework consists of three stages: designing the framework, weighting the framework and assessment method, and presenting the case study. Some specific methods were used including literature reviews, group discussions (interviews and seminars), questionnaire surveys, and case studies [34].

7. In disaster mitigation, there is a formulation of framework of community preparedness in anticipation of natural disaster. The process of formulating the framework includes: identifying critical preparedness factors, identifying indicators according to 
stakeholders, analysing instruments, conducting trials (adaptation), improving frameworks and instruments [35].

The methodology formulation that is adopted as a reference in this study is based on Bassioni formulation [23], since it provides more detailed criteria and steps to develop the framework. The criteria or requirements cover basic framework development, reference framework selection, and steps to formulate the framework.

\section{Proposed Methodology}

The proposed methodology for developing a sustainable procurement framework of construction works in Indonesia is based on four founding frameworks as depicted in Figure 1.

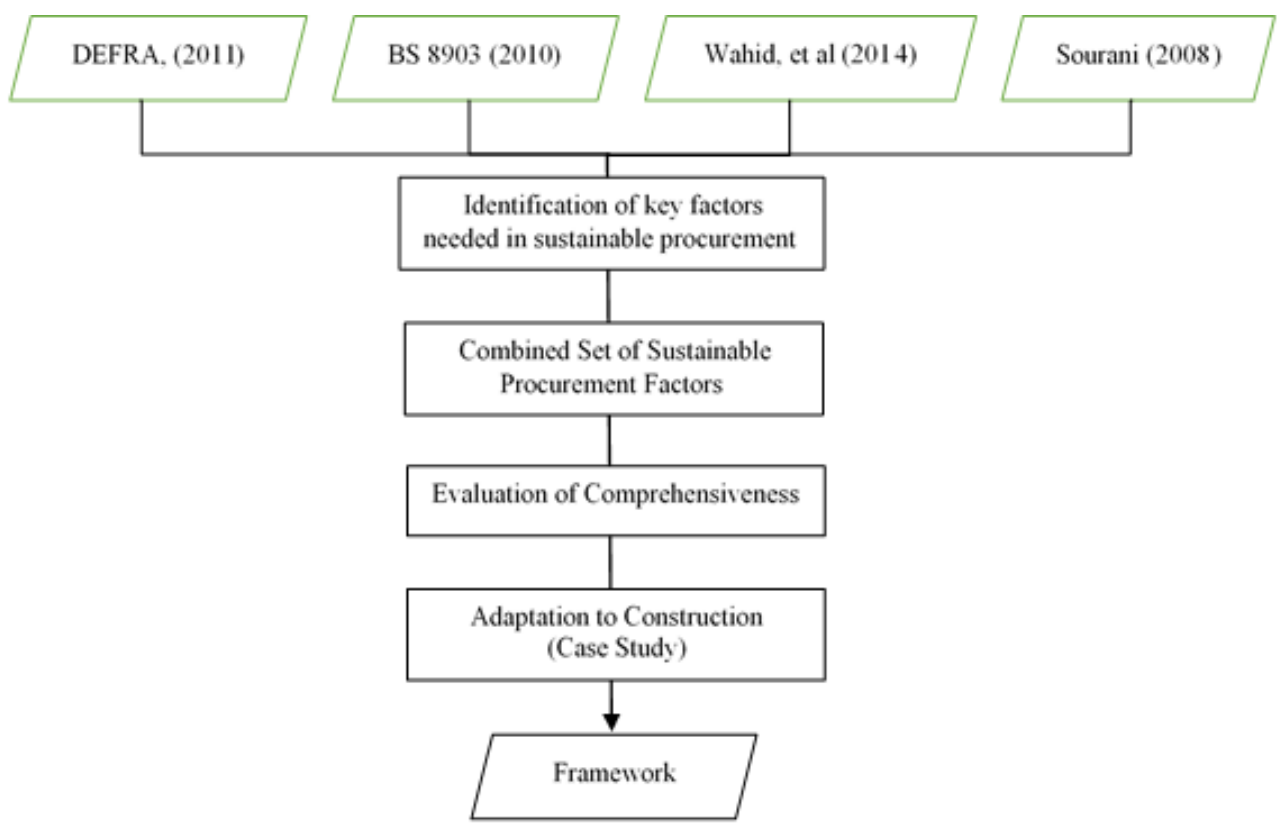

Fig. 1. The Methodology for Framework Development.

Considering that sustainable construction procurement in Indonesia is a relatively new topic, information related to sustainable procurement plans and practices are still limited, the explorative approach is then selected for this study. The study will begin with critical literature studies related to sustainable procurement practices in developed and developing countries. Moreover, Indonesian condition and practices in construction procurement were also gathered to set the context for the framework. The methodology for developing the framework as depicted in Figure 1 is then applied.

The proposed framework would be a new framework that is developed from the frameworks that have been formulated and defined: combination of sustainable procurement framework according to DEFRA, BS 8903, Wahid, and Sourani. Whilst, the framework formulation is done by combining founding frameworks, the identification of important factors in sustainable construction procurement will be based on challenges identified in practicing the sustainable procurement. 
The sustainable procurement elements from four founding frameworks will be used to develop further the factors to build the framework, i.e., Human Resource, Policy, Communication, Process, Supplier Engagement, Monitoring and Reporting, Leadership, Priorities, Targets, Standards, Participation, Support Mechanisms, Action Plans, Knowledge and Perceptions, Politics and Regulations, Contracts, Instruments and Finance. To identify the important factors data collection will be done by utilizing semi structured interview and questionnaire. The targeted respondents would include practitioners and academia related to construction procurement and sustainability issues. A Delphi method may be used to converge the opinions on challenges to identify the important factors for sustainable construction procurement.

The obtained factors are then analyzed descriptive statistics to understand each factor and its relation to others. PLS-SEM would be used to find the dynamic and complex relationship between factors. While, the validation would be made based on opinions and case studies to public and private sector owners using several interviews as well as a focus group discussion session. The methodology of developing the framework for sustainable construction procurement in Indonesia could be summarized in Table 3.

Table 3. The proposed sustainable procurement framework methodology

\begin{tabular}{|c|c|c|c|}
\hline Stage & Description & Method & Output \\
\hline $\begin{array}{l}\text { Theoretical } \\
\text { study }\end{array}$ & $\begin{array}{l}\text { Identify problems and set } \\
\text { research goals }\end{array}$ & Literature Study & $\begin{array}{l}\text { Research purposes } \\
\text { and questions }\end{array}$ \\
\hline $\begin{array}{l}\text { Literature } \\
\text { Review }\end{array}$ & $\begin{array}{l}\text { Concepts and best practices } \\
\text { of sustainable construction } \\
\text { procurement in UK, } \\
\text { European countries, } \\
\text { Canada, Malaysia, Ghana }\end{array}$ & Literature Study & $\begin{array}{l}\text { Definition, } \\
\text { challenges and } \\
\text { opportunities of } \\
\text { Sustainable } \\
\text { Construction } \\
\text { Procurement (SCP) }\end{array}$ \\
\hline $\begin{array}{l}\text { Identify } \\
\text { challenges in } \\
\text { implementation } \\
\text { of sustainable } \\
\text { procurement }\end{array}$ & $\begin{array}{l}\text { Identify challenges related } \\
\text { to application of } \\
\text { sustainable procurement } \\
\text { principles to procurement } \\
\text { policies and strategies, } \\
\text { processes and organizations }\end{array}$ & $\begin{array}{l}\text { Data was } \\
\text { collected by } \\
\text { semi-structured } \\
\text { interview. } \\
\text { Analysis is } \\
\text { descriptive. }\end{array}$ & $\begin{array}{l}\text { Factors influencing } \\
\text { implementation of } \\
\text { SCP }\end{array}$ \\
\hline $\begin{array}{l}\text { Identify } \\
\text { important factors } \\
\text { driving the } \\
\text { implementation } \\
\text { of SCP }\end{array}$ & $\begin{array}{l}\text { Identify key factors needed } \\
\text { to achieve sustainable } \\
\text { procurement }\end{array}$ & $\begin{array}{l}\text { Three-stage } \\
\text { Delphi method } \\
\text { and closed } \\
\text { questionnaires } \\
\text { using Likert } \\
\text { scale. }\end{array}$ & $\begin{array}{l}\text { Important factors } \\
\text { needed for SCP } \\
\text { implementation }\end{array}$ \\
\hline $\begin{array}{l}\text { Identify } \\
\text { relationship } \\
\text { between factors }\end{array}$ & $\begin{array}{l}\text { Identify significance of } \\
\text { relationships among factors }\end{array}$ & $\begin{array}{l}\text { PLS, } \\
\text { Descriptive } \\
\text { Analysis }\end{array}$ & $\begin{array}{l}\text { Framework analysis } \\
\text { results }\end{array}$ \\
\hline $\begin{array}{l}\text { Comprehensive } \\
\text { Evaluation } \\
\text { (Analysis) }\end{array}$ & $\begin{array}{l}\text { Evaluate or analyze } \\
\text { comprehensively against } \\
\text { these factors and } \\
\text { responsibility of actors }\end{array}$ & $\begin{array}{l}\text { Focus Group } \\
\text { Discussion } \\
\text { (FGD) with } \\
\text { practitioners } \\
\text { and experts; } \\
\text { Descriptive } \\
\text { Analysis }\end{array}$ & $\begin{array}{l}\text { Framework } \\
\text { validated } \\
\text { opinions }\end{array}$ \\
\hline $\begin{array}{l}\text { Adaptation to } \\
\text { Construction } \\
\text { (Case Study) }\end{array}$ & $\begin{array}{l}\text { Conduct case studies to test } \\
\text { the framework }\end{array}$ & $\begin{array}{l}\text { Case study and } \\
\text { interviews }\end{array}$ & $\begin{array}{l}\text { Framework is } \\
\text { validated by cases }\end{array}$ \\
\hline
\end{tabular}




\section{CONCLUSIONS}

Since Indonesia just arrived at planning to adopt the sustainable procurement initiative for delivering sustainable construction, there is a need to develop a comprehensive sustainable construction procurement framework (SCPF). This paper presented the development of methodology to formulate the framework. The formulation accommodates four main steps, i.e., identification of important elements of reference frameworks, identification of underlying relationship, compressive evaluation of the framework, and adaption to through case studies. The research itself would produce a framework (SCPF) that will serve as a reference in implementing sustainable procurement in construction projects, in the Indonesian context, for all actors. This SCPF also will contribute to capacity development of participant and stakeholders in SCP endeavour.

\section{References}

1. M. Abduh, R. Wirahadikusumah, D. Chomistriana, AC, 18 (2012)

2. P. A. Bullen, P. R. Davis, Sustainable Construction and Procurement (FBE Art\&Design, CUT, 1987)

3. CIB, Agenda 21 (CIB, Report Publication, 1999)

4. PUPR, SC, 05 (2015)

5. A. Sev, Sust. Dev. J., 17, 161-173 (2009)

6. M. Martins, Procurement (Sage Publications, Thousand Oaks, 2009)

7. G.A. Sears, S.K. Sears, R.H. Clough, Construction Project Management, 5 (2008)

8. I. Adetunji, A. Price, P. Fleming, P. Kemp, Proceedings of ICE, 156, 4 (2003)

9. T. Hakkinen, and K. Belloni, Barriers and drivers SB (VTT, TRC Finland, 2011)

10. L. Preuss, SCM. J. 14, 213-223, (2009)

11. R. Ruparathna, K. Hewage, JoCP., 109, 305-314 (2015)

12. J. Sarkis, L.M. Meade, A.R. Presley, JoCP., 31, 40-53 (2012)

13. M. Abduh, J. Juwana, Asia Cons. Conference, 21 (2016)

14. C. Bratt, S. Hallstedt, K. Robèrt, G.I. Broman, J. Oldmark, JCP, 52, 309-316 (2013)

15. R. Wirahadikusumah, M. Abduh, Y. Messah, M. Aulia and A. Yang, JoCM (to be published)

16. Y. Messah, R. Wirahadikusumah, M. Abduh, Prosiding KN-ILT.UII, 4, 293-305 (2017)

17. M. Webster, Dictionary (1982)

18. Cambridge, Dictionary (Camb. Univ. Press, 2018)

19. Oxford, Dictionary (Oxford Dictionaries, 2014)

20. DSA, Annual Report (Gov. UK, 2011)

21. Uclan, EMS, FM ENV 014 (2018)

22. Scotland Procurement Direction, Sustainable Procurement Action Plan (2009)

23. H. A. Bassioni, A. D. F. Price, T. M. Hassan, JoME (ASCE), 20, 42-50, (2004)

24. DEFRA, Sustainable Procurement in Government Flexible Framework (2006)

25. BSI, Principles and Framework for Procuring Sustainably, 8903 (2010)

26. S. N. Wahid, S. A. Sazalli, Z. Ramli, Proceeding FIG Congress, 7047 (2014) 
27. A. Sourani, Proceedings of the ICE - Management. (Lboro, 2008)

28. A. Kashkool, Sustainable Procurement for Construction Project (Scholar Press, 2015)

29. M. Kennard, Sustainable Procurement, XXIII FIG Congress, TS8 (2006)

30. T.Y. Koh, S. Rowlinson, M. Tuuli, A. Liu, RICS-HK Annual Conference, 10 (2011)

31. M. Bohari, A. Alia, Bo Xia, Eng. Proj. Prod. Manag. Conference, 7 (2015)

32. M. Thunberg, Supply Chain Planning (Science and Technology, Linköping Univ, 2016)

33. N. K. M. Isa, Z. A. Samad, A. Alias, JBP, V, 1 (2014)

34. Z. Jin, F. Deng, H. Li, M. Skitmore, Cons. Eng. Manag., ASCE, 139, 1154-1167 (2013)

35. LIPI, Frame. dev. Comm. anticipating natural disasters (2006)

\section{Attachment}

Descriptions for of the Identified Elements of Sustainable Procurement

\begin{tabular}{|c|c|c|}
\hline No & Elements & Descriptions \\
\hline 1 & People & $\begin{array}{l}\text { People always plays very important role in a change management to } \\
\text { introduce and implement new concept and practices, such as } \\
\text { sustainable procurement. This element may relate to efforts in capacity } \\
\text { building of each individual person involved in the procurement for all } \\
\text { level of management. Moreover, this element should also consider how } \\
\text { to identify champions and agents of change that will enable the } \\
\text { introduction and implementation of new concept or practices effective. } \\
\text { Training programs should be developed based on this element. }\end{array}$ \\
\hline 2 & $\begin{array}{l}\text { Policy and } \\
\text { Strategy }\end{array}$ & $\begin{array}{l}\text { Policy is formally expressing the procurement intentions, objectives } \\
\text { and values of the organization. The policy related to sustainable } \\
\text { procurement should be clearly aligned to the organization's policy for } \\
\text { sustainability development. This policy will be used as the basis for } \\
\text { procurement operations. Meanwhile, the strategy will outline how the } \\
\text { organization's procurement intentions and directions be delivered by } \\
\text { the existence of clear key objectives and targets. }\end{array}$ \\
\hline 3 & Communication & $\begin{array}{l}\text { Communication is key to spread both policy and strategy to all } \\
\text { individual involved in the procurement. Moreover, communication is } \\
\text { the key for effective interactions between individual and parties } \\
\text { involved in procurement, and between procurement's function and the } \\
\text { rest of organization; with different ways of technologies, techniques, } \\
\text { methods, and channels. }\end{array}$ \\
\hline 4 & Process & $\begin{array}{l}\text { This element related to implement sustainable principles into the } \\
\text { procurement process; starting from the planning stage up to reviewing } \\
\text { and learning from the contract. Best practices of this element would be } \\
\text { conducting expenditure analysis and prioritization, sustainability risk } \\
\text { analysis for high profile contracts, ensuring key contracts incorporate } \\
\text { sustainability criteria, identification and reduction supply chain } \\
\text { sustainability risks. }\end{array}$ \\
\hline 5 & $\begin{array}{l}\text { Engaging } \\
\text { Supplier }\end{array}$ & $\begin{array}{l}\text { This element is specifically related to efforts of communicating and } \\
\text { engaging with suppliers as they interact from the first time to the end of } \\
\text { the procurement process. As a best practice, it could start with making } \\
\text { organization open and transparent to suppliers that will encourage a } \\
\text { range of different types of suppliers to involved in the procurement and } \\
\text { then be exposed to sustainable procurement concepts and practices. }\end{array}$ \\
\hline 6 & $\begin{array}{l}\text { Monitoring and } \\
\text { Reporting }\end{array}$ & $\begin{array}{l}\text { This element focuses on the achievement and measurement results in } \\
\text { sustainable procurement throughout its processes. Reporting on the }\end{array}$ \\
\hline
\end{tabular}




\begin{tabular}{|c|c|c|}
\hline No & Elements & Descriptions \\
\hline & & $\begin{array}{l}\text { compliance of each process is mandatory. The objective is not only to } \\
\text { measure the impacts of actions taken in support of procuring } \\
\text { sustainability but also to demonstrate the results arising from these } \\
\text { actions. }\end{array}$ \\
\hline 7 & Leadership & $\begin{array}{l}\text { Leadership is always important in any endeavor, including in the } \\
\text { procurement context as well as in promoting the sustainable } \\
\text { procurement concepts and practices. Involving many parties in } \\
\text { complex procurement processes with a new paradigm will need strong } \\
\text { leadership. }\end{array}$ \\
\hline 8 & Priority & $\begin{array}{l}\text { Priority should be made related to risk involved in a sustainable } \\
\text { procurement. By setting priorities, the organization could focus its } \\
\text { efforts on managing risks (including opportunities) and to deliver the } \\
\text { maximum contribution to sustainable development. }\end{array}$ \\
\hline 9 & Target & $\begin{array}{l}\text { Target should be made as a destination for one period of time of the } \\
\text { sustainable procurement implementation. The target should always be } \\
\text { an achievement that is hard to get while it should also be achievable. }\end{array}$ \\
\hline 10 & Standards & $\begin{array}{l}\text { The existence of standards can help those engaged in procurement } \\
\text { activities to better perform their tasks and it can promote uniform and } \\
\text { generic procurement documents. Moreover, its internationally } \\
\text { harmonized process can serve as a basis for developing consistent } \\
\text { curricula for procurement education. }\end{array}$ \\
\hline 11 & Participation & $\begin{array}{l}\text { Participation is strong involvement of all parties in all procurement } \\
\text { processes to integrate the sustainability principles as much as they } \\
\text { could. }\end{array}$ \\
\hline 12 & $\begin{array}{l}\text { Support } \\
\text { Mechanism }\end{array}$ & $\begin{array}{l}\text { Supports in form of subsidies and funds, procurement resources such as } \\
\text { green specification, reward for good practice and sustainable product } \\
\text { labelling are necessary to accelerate the integration of sustainable } \\
\text { principles into procurement. }\end{array}$ \\
\hline 13 & Action Plan & $\begin{array}{l}\text { Action plan is a proposed course of actions related to sustainable } \\
\text { procurement. It would consist of specific actions and commitments } \\
\text { related to each of the strategic objectives and desired outcomes for a } \\
\text { defined time. }\end{array}$ \\
\hline 14 & $\begin{array}{l}\text { Knowledge and } \\
\text { Perception }\end{array}$ & $\begin{array}{l}\text { To influence the procurement process effectively, individual involved } \\
\text { in procurement process requires knowledge and commitment. Proper } \\
\text { knowledge related to sustainable procurement is necessary to shape the } \\
\text { individual's perception on an issue that may lead to commitment } \\
\text { building by the individual. }\end{array}$ \\
\hline 15 & Regulation & $\begin{array}{l}\text { Regulation as the means to implement the policy is needed in an } \\
\text { organization. However, the regulation that is to detailed will block } \\
\text { innovations from the sustainable procurement processes, that is } \\
\text { counterproductive. }\end{array}$ \\
\hline 16 & Contract & $\begin{array}{l}\text { Contract is the heart of any procurement that explains and guards all } \\
\text { rights and requirements of each party involved in delivering the } \\
\text { intended value of the customers. Sustainability principles are needed to } \\
\text { be addressed clearly in a contract for the delivery, including } \\
\text { sustainability as a primary goal and integrating sustainability } \\
\text { requirements into contract specifications and conditions. }\end{array}$ \\
\hline 17 & Instrument & $\begin{array}{l}\text { Instrument is needed to monitor and to assess the implementation and } \\
\text { the achievement of the sustainable procurement. }\end{array}$ \\
\hline 18 & Finance & $\begin{array}{l}\text { Since the implementation of sustainable procurement involves risk } \\
\text { associated with the integration of sustainability principles into its } \\
\text { processes, the financial aspect should be clearly defined at the first } \\
\text { place. Higher cost of investment at the initial stage would always be } \\
\text { considered in implementing the sustainability principles, yet the total } \\
\text { cost of it should be lesser. }\end{array}$ \\
\hline
\end{tabular}

